\title{
既存コンクリート系建築物に打ける鉄筋のガス圧接継手の 継手強度の再評価に関する研究十
}

\author{
田中 礼 治* 大芳賀 義 喜** \\ 熊 谷 元 行** 小澤昌 広** \\ Revaluation of the Strength of Gas-Pressure Welded Joints \\ Used in the Existing Concrete Structural Buildings
}

by

\author{
Reiji Tanaka*, Yosiki Ohaga ${ }^{* *}$, Motoyuki Kumaga ${ }^{* *}$ \\ and Masahiro Ozawa**
}

\begin{abstract}
The strength of gas-pressure welded joint is evaluated as strong as the strength of the using reinforcement. But, many gas-pressure welded joints were damaged in RC and SRC structural buildings at the 1995 Hyogoken Nanbu Earthquake. After earthquake, we picked up 365 test pieces of gas-pressure welded joints from the damaged $\mathrm{RC}$ and SRC structural buildings, and those pieces were tested by the tension test. The $12.6 \%$ pieces in all test specimens were fractured. Therefore, the strength of gas-pressure welded joints in the existing concrete structural buildings are not able to apply the present evaluation. This paper is a study on the revaluation of strength of gas-pressure welded joints. The strength of gas-pressure welded joints were revaluated by the research data of Hyogoken Nanbu Earthguake and another test data of 23 public experiment institution in Japan. From the research of this study, we took mainly the following conclusions.

(1) The strength of gas-pressure welded joint used in the existing concrete structural buildings were not evaluated as strong as the strength of the using reinforcement.

(2) We proposed the method of revaluation of the strength for gas-pressure welded joints used in the existing concrete structural buildings.
\end{abstract}

Key words : Existing concrete structural buildings, Strength of gas-pressure welded joint, 1995 Hyogoken Nanbu Earthquake

\section{1 は じ.めに}

コンクリート系構造物に使用されている鉄筋のガス圧 接継手の継手強度は従来，母材とほぼ同等であるとして 扱われてきた.

このことについては，筆者等は文献 1 において全国の 公的試験機関 (23 機関) が依頼されて行った，約 95 万 本という多数本の引張試験の調查結果より, 継手破断す る継手の比率（以下，継手破断比率）の平均值が $0.48 \%$ と小さくガス圧接継手の継手性能が安定していること, また, この結果から継手強度は母材とほぼ同等に評価し て良いことを確認している。

しかし，兵庫県南部地震では既存コンクリート系建築 物で使用されていた鉄筋のガス圧接継手に多数の継手破 断の被害が発生した.

そこで地震後, 現地の 8 棟の被害建物から解体時に採 取した 365 本のガス圧接継手試験片について引張試験を 行い, 継手破断比率について調查を行った. その結果， 継手破断比率の平均値は $12.6 \%$ であった。この值は文献 1 での継手破断比率の平均值 $0.48 \%$ の約 26 倍と大きい.
このことは既存コンクリート系建築物で使用されている ガス圧接継手の中には相当に高い比率で継手破断するも のが混入していることを示していると同時に, 既存コン クリート系建築物の耐震診断ならびに耐震改修に当たっ ては，ガス圧接継手の継手破断の影響を考慮しなければ ならないことを示唆している。

上述したように, ガス圧接継手の継手強度は従来, 母 材とほぼ同等であると評価されてきたわけであるが，兵 庫県南部地震後の調査結果から考えて, 既存建築物で使 用されているガス圧接継手の継手強度に, 従来の評価を そのまま適用するのは困難である, 即ち, 継手強度に関 しては, 継手破断強度の分布を考慮した新たな再評価が 必要である。

そこで本報では，具体的に次の 3 項目について検討し たので報告する.

(1) 兵庫県南部地震でのガス圧接継手の被害を外観調 查により統計的に確認した.

(2) 被害建物 8 棟から採取したガス圧接継手試験片の 引張試験結果より, ガス圧接継手の継手強度の再評価の

$\dagger$ 原稿受理 平成 10 年 11 月 18 日 Received Nov. 18, 1998

* 正 会 員 東北工業大学工学部建築学科 ７982-8577 仙台市太白区八木山香澄町, Dept. of Architecture, Tohoku Inst. of Tech., Taihaku-ku, Sendai, 982-8577

** 東北工業大学工学部建築学科 †982-8577 仙台市太白区八木山香澄町, Dept. of Architecture, Tohoku Inst. of Tech., Taihaku-ku, Sendai, 982-8577 
必要性を指摘した。

（3）兵庫県南部地震での調査データおよび全国の公的 試験機関の調查データをもとに，ガス圧接継手の継手強 度の再評価を行った。

本報で示したデータは，現在行われている既存コンク リート系建築物の耐震診断, 耐震改修において, ガス圧 接継手の安全性を評価する基礎データとして十分利用で きると考えている。

\section{2 兵庫県南部地震以外のガス圧接継手の被害}

兵庫県南部地震ではガス圧接継手に多数の継手破断被 害が発生した。過去の地震被害報告書 ${ }^{2), 3)}$ の中には，ガ ス圧接継手の被害についてほとんど述べられていない。 そのため, 兵庫県南部地震のガス圧接継手の被害が地域 的な特異性を保有しているように見える。しかし，筆者 等の調查によると兵庫県南部地震以前の宮城県沖地震, 三陸はるか沖地震でもガス圧接継手が地震被害を受けて いた事例があり，ガス圧接継手の地震被害を受ける機会 は地域的な特異性はなく, 全国的であることが分かる。

以下に示す宮城県沖地震，三陸はるか沖地震の場合と も，ガス圧接継手はせん断破壞した柱部材で使用されて いたものである。継手に作用した応力がさほど大きくな く継手は健全であった。このような部材中央に設置され たガス圧接継手が部材のせん断破壊後も健全であった事 例は兵庫県南部地震でも多数見られた。

\section{$2 \cdot 1$ 宮城県沖地震での事例}

Fig. 1 は宮城県沖地震（1978 年）で見られた事例で ある。この事例はガス圧接継手が地震後, 目視確認され た我が国最初のものではないかと考光ている。

柱部材はせん断破壊しているが，ガス压接継手は健全 である、鉄筋は丸鋼である。

\section{$2 \cdot 2$ 三陸はるか沖地震での事例}

Fig. 2 は三陸はるか沖地震（1994 年）で見られた事例 である。柱部材はせん断破壊しているが，ガス圧接継手 は健全である，鉄筋は丸銅である。

\section{3 兵庫県南部地震におけるガス圧接継手の}

\section{継手破断被害に関する外観調查}

\section{$3 \cdot 1$ 調查概要および調査結果}

調査した建物の全棟数は 60 棟である. 調査棟数 60 棟 は人的な調査能力によるもので，特に理由のある数值で はない，各建物の調査に当たっては，各建物全体にわた つて調査可能な範囲について詳細に調查を行った。調查 した建物のうち，ガス圧接継手が露出し，外観からガス 圧接継手が確認できた建物は全部で 22 棟あった。 22 棟 の建物用途の内訳は公共建築物 3 棟，商業ビル 4 棟，集 合住宅 15 棟である。

確認できたガス圧接継手の全箇所数は 279 籄所である. その内で継手破断していた箇所数は 31 箇所であった。

被害状況の一例を Fig. 3 に示した。柱主箭の大部分が 継手破断している。

ガス圧接継手が確認できた建物 22 棟中， 7 棟で破断が 確認された。ガス圧接継手の破断が建物被害に大きく影 響を及ぼしたと考えられる建物は1棟のみであった。そ

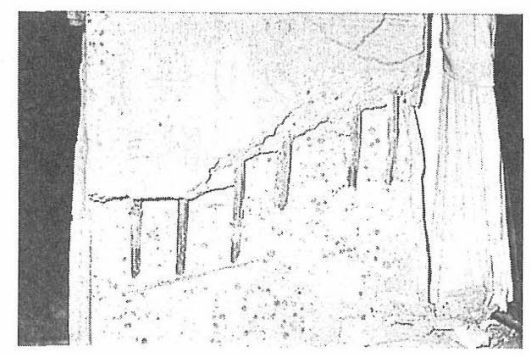

Fig. 1. Damage of gas-pressure welded joints.

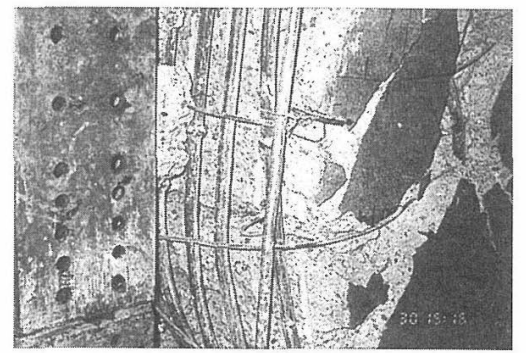

Fig. 2. Damage of gas-pressure welded joints.

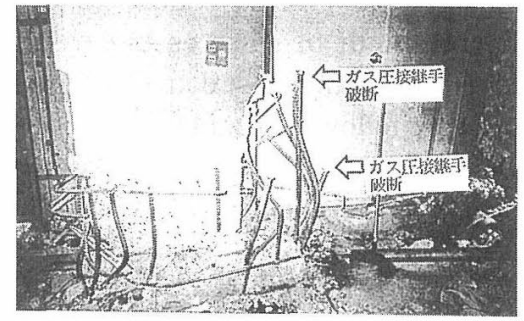

Fig. 3. Many fractured gas-pressure welded joint in longitudinal reinforcements of column.

の建物は Fig. 3 に示してあるように，1階柱脚の主筋の 大半が継手破断しており，継手破断により柱が圧壊し， 建物が大破している。継手破断の原因は曲げ応力による ものと考えられる。

その他の継手破断が見られた 6 棟は主に柱のせん断破 壞であったため, 継手破断がどの程度建物被害に影響を 及ぼしたかは明確に出来なかったが, 主筋の継手破断が 間接的に建物被害に影響を及ぼしたと考えることは決し て誤った判断ではないと思われる。

\section{$3 \cdot 2$ 外観調查のまとめ}

外観調査の結果より継手破断に関して次のことが認め られた。

(1) 調査建物 60 棟の内，外観からガス压接継手が確 認できた建物は 22 棟あった。その 22 棟中継手破断が 7 棟で見られ，継手破断が見られた建物の比率がかなり 高い。

（2）継手破断が確認された 7 棟の内，継手破断が建物 被害に大きく影響を及ぼしたと考えられる建物は 1 棟の みであった。

（3）外観から確認されたガス圧接継手のみについて単 純にガス圧接継手の継手破断比率を求めてみると，31/ $279=11.1 \%$ となる。 
(4) 継手の設置位置が確認できた継手 207 箇所の内, $\mathrm{RC}$ 規準の規定内のものが 165 箇所 $(80 \%)$, 規定外のも のが 42 箇所 $(20 \%)$ と, 設置位置については RC 規準が 比較的よく順守されていることが認められた。

(5) 設置位置が RC 規準の規定内の継手では継手破断 比率が $5 \%$ と小さく，規定外のものの継手破断比率は $30 \%$ と大きい．このことから考えると， RC 規準の継手設置 位置の規定が今回の地震におけるガス圧接継手破断の被 害を軽減することに大きく貢献したものと考えられる。

\section{4 被害建物から採取したガス圧接継手試験片の 引張試験調査}

\section{$4 \cdot 1$ ガス圧接継手試験片および引張試験方法}

ガス圧接継手試験片を採取した建物数は 8 棟である. 試験片の採取は建物の解体と同時に行った. 採取部位は 建物の所有者に一任したが，ほとんどが柱部材からの採 取であった。試験片の採取は全てガス溶断によったが, 溶断位置は継手部に熱影響を及ぼさないように継手位置 より $60 \mathrm{~cm}$ 以上離すように指示したが，採取試験片は全 て指示通りであり，継手への熱影響はほとんどないと考 えられる。

Table Iにガス圧接継手試験片（以下，試験片という） を採取した建物および採取した試験片本数を示した。

建物の地震被害ランクはいずれも大破である。採取し た試験片本数は全部で 365 本である.

引張試験方法は, JIS Z 3120 (鉄筋コンクリート用棒 鋼ガス圧接継手の調查方法）に従って行った。

\section{$4 \cdot 2$ 引張試験結果}

$4 \cdot 2 \cdot 1$ 継手強度の再評価の必要性 Table II は, 建物毎の継手破断比率を示したものである. 継手破断比 率とは, 試験片本数 (A) で継手破断した試験片数 (B) を除した值である.

Table IIより次のことが認められる.

（1）建物別の継手破断比率は $0 \sim 27.3 \%$ の広範囲に分 布し, 継手破断比率は各建物によって異なるが, 全平均 は $12.6 \%$ と大きい.

(2) Table II の継手破断比率の平均值 $12.6 \%$ は，文献 1 での継手破断比率の平均值 $0.48 \%$ の約 26 倍と大きい. このことは既存コンクリート系建築物で使用されている ガス圧接継手の中には相当に高い比率で継手破断するも のが混入していることを示していると同時に, 既存コン クリート系建築物の耐震診断ならびに耐震改修する場合 にガス圧接継手の継手破断の影響を考慮しなければなら ないことを示唆している.

(3) ガス圧接継手の継手強度に関する従来の評価は 「NAK 仕様書」の検査の合格規準でもあり，かつ文献 1 でも確認されているように，ほぼ母材と同等であるとし て扱われてきたが, Table II の継手破断比率の平均值が $12.6 \%$ であることから考えると，既存建築物で使用され ているガス圧接継手の継手強度に関しては従来の評価を そのまま適用するのには無理があると考えられる。即ち， 既存コンクリート系建築物で使用されているガス圧接継 手の継手強度については継手破断強度の分布も考慮し再
Table I . Buildings picked up test specimens and number of specimens of gas-pressure welded joints.

\begin{tabular}{|c|c|r|r|}
\hline $\begin{array}{c}\text { Name of } \\
\text { buildings }\end{array}$ & $\begin{array}{c}\text { Location } \\
\text { (Name of city) }\end{array}$ & $\begin{array}{c}\text { Construction } \\
\text { year }\end{array}$ & $\begin{array}{r}\text { Number of } \\
\text { specim ens }\end{array}$ \\
\hline No.1 & KOBE & 1967 & 23 \\
\hline No.2 & KOBE & 1957 & 94 \\
\hline №.3 & KOBE & 1982 & 22 \\
\hline No.4 & ASHIYA & 1970 & 11 \\
\hline No.5 & KOBE & 1987 & 94 \\
\hline №.6 & KOBE & 1971 & 24 \\
\hline No.7 & NISHINOMIYA & 1968 & 31 \\
\hline No.8 & KOBE & 1985 & 66 \\
\hline Total & & & 365 \\
\hline
\end{tabular}

Table II. Fracture ratio of joint in each buildings.

\begin{tabular}{|c|r|r|l|}
\hline $\begin{array}{c}\text { Name of } \\
\text { buildings }\end{array}$ & $\begin{array}{c}\text { Number of } \\
\text { specimens } \\
\text { (A) }\end{array}$ & $\begin{array}{c}\text { Number of } \\
\text { fractured } \\
\text { join ts } \\
\text { (B) }\end{array}$ & $\begin{array}{l}\text { Fracture } \\
\text { ratio of } \\
\text { joint } \\
(\mathrm{B}) /(\mathrm{A}) \%\end{array}$ \\
\hline №.1 & 23 & 1 & 4.3 \\
\hline №.2 & 94 & 1 & 1.1 \\
\hline №.3 & 22 & 0 & 0.0 \\
\hline №.4 & 11 & 3 & 27.3 \\
\hline №.5 & 94 & 19 & 20.2 \\
\hline №.6 & 24 & 3 & 12.5 \\
\hline No.7 & 31 & 6 & 19.4 \\
\hline №.8 & 66 & 13 & 19.7 \\
\hline Total & 365 & 46 & 12.6 (Ave.) \\
\hline
\end{tabular}

Table III. Relationship between building use and fracture ratio of joint.

\begin{tabular}{|c|c|c|c|c|}
\hline $\begin{array}{c}\text { Building } \\
\text { use }\end{array}$ & $\begin{array}{l}\text { Name of } \\
\text { buildings }\end{array}$ & \begin{tabular}{|c} 
Number of \\
specimens \\
(A)
\end{tabular} & $\begin{array}{l}\text { Number of } \\
\text { fractured } \\
\text { joints (B) }\end{array}$ & $\begin{array}{l}\text { Fracture } \\
\text { ratio of joint } \\
(\mathrm{B}) /(\mathrm{A}) \%\end{array}$ \\
\hline $\begin{array}{l}\text { Public } \\
\text { buildings }\end{array}$ & $\begin{array}{ll}\mathrm{N} 0.1 \\
\mathrm{~N} 0.2\end{array}$ & 117 & 2 & 1.7 \\
\hline $\begin{array}{l}\text { Private } \\
\text { multiple } \\
\text { dwelling } \\
\text { houses }\end{array}$ & 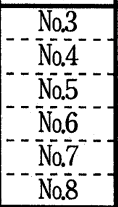 & 248 & 44 & 17.7 \\
\hline \multicolumn{2}{|l|}{ Total } & 365 & 46 & 12.6 (Ave.) \\
\hline
\end{tabular}

評価が必要である.

$4 \cdot 2 \cdot 2$ 継手破断強度の検討用データ Table II の建 物別の継手破断比率を公共建築物と民間の集合住宅の建 物別用途に分類し示したのが Table IIIである.

Table IIIから分かるように, 公共建築物の継手破断比 率の平均値は $1.7 \%$ と民間の集合住宅の $17.7 \%$ より相当に 小さく，建物の用途によって継手破断比率が異なること が分かる.これら継手破断比率の相違の主たる理由とし ては施工精度ならびに施工管理の良否によるものと思わ れる。

Table III の集合住宅から採取した試験片の詳細を Table IV に示した. Table IIIの民間の集合住宅の試験片 数が 248 本で Table IVのそれが 206 本になっているのは, Table IVでは丸鋼（42 本）が除かれているためである. 鉄筋種別として SD30 と SD35の 2 種があり, SD30 は試 験片本数が 24 本と少ない。 そこで, 本報では Table IV 
Table IV . Fracture ratio of joint picked up from private multiple dwelling houses.

\begin{tabular}{|c|c|c|c|c|}
\hline $\begin{array}{c}\text { Building } \\
\text { use }\end{array}$ & $\begin{array}{l}\text { Classification } \\
\text { of } \\
\text { reinforcement }\end{array}$ & $\begin{array}{c}\text { Number of } \\
\text { specimens } \\
\text { (A) }\end{array}$ & $\begin{array}{l}\text { Number of } \\
\text { fractured } \\
\text { joints (B) }\end{array}$ & $\begin{array}{l}\text { Fracture } \\
\text { ratio of joint } \\
\text { (B) } /(\mathrm{A}) \%\end{array}$ \\
\hline \multirow{2}{*}{$\begin{array}{c}\text { Private } \\
\text { multiple } \\
\text { dwelling } \\
\text { houses }\end{array}$} & SD30 & 24 & 8 & 33.3 \\
\hline & SD35 & 182 & 32 & 17.6 \\
\hline & Total & 206 & 40 & 19.4 (Ave.) \\
\hline
\end{tabular}

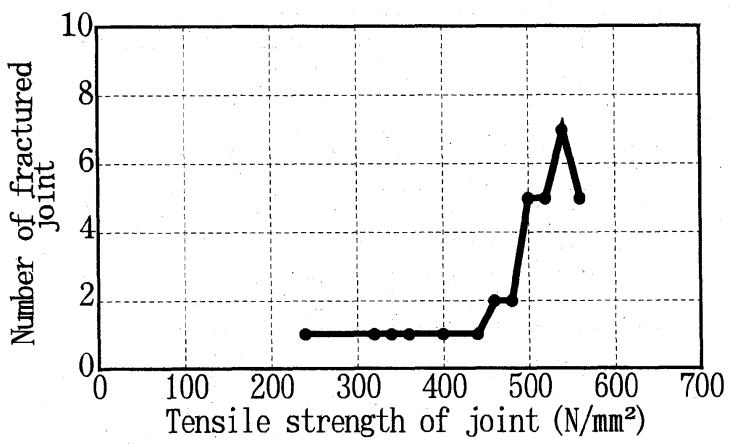

Fig. 4. Distribution of tensile strength of SD35 deformed bars fractured at joint.

の民間の集合住宅のデータから得られた SD35 の継手破 断した試験片本数 32 本を継手破断強度の検討用データ として採用した。

継手破断強度の検討用データ（SD35，32 本）の破断 強度分布をダイヤアグラムで示したのが Fig. 4 である. この兵庫県南部地震の採用データを以下, 兵庫データと 呼ぶ.

\section{5 全国の公的試験機関における引張試験調查}

\section{$5 \cdot 1$ 調查の概要}

全国の公的試験機関（23 機関）が 1982 年 1986 年 の 5 年間にガス圧接継手の現場の施工管理用の拔取試験 片として依頼されて行った約 95 万本の引張試験結果の 調査である。調查範囲は鉄筋種別として SD30, SD35 の 2 種，鉄筋径はD $16 ＼mathrm{~ D ~} 32$ である. 本報でこの調查を採 用した主たる理由は，現場での抜取試験片ということで 既存建築物でのガス圧接継手と見なせることが考えられ るためである.

全国の公的試験機関の分布を Fig. 5 に示した. 試験機 関は北海道から九州まで全国的に分布している. Table $\mathrm{V}$ に試験片の全数を各年度ごとに示した。全調査試験片 数は 953424 本である。

Table VIは全試験片の各年度ごとの継手破断比率を示 したものである。継手破断したものは，953424 本中 4551 本あった。平均継手破断比率は $0.48 \%$ であった。調查試 験片を, SD30 と SD35 別に継手破断比率を調べたのが Table VIIである. SD35 の比率がSD30 のそれより多少大 きい.

Fig. 6 は試験機関別の継手破断比率を示したものであ る。継手破断比率には多少の地域差は見られるが, 継手 破断比率が $1.0 \%$ を越す試験機関はない。試験機関№. 17

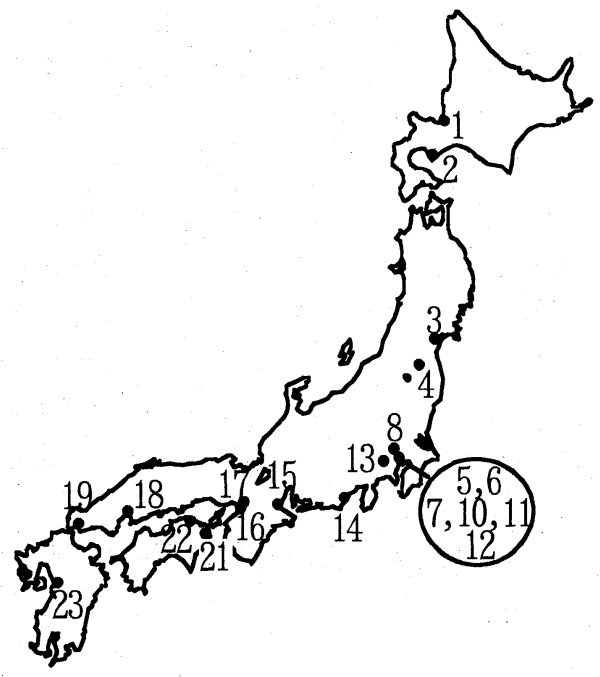

Fig. 5. Location of Public Experiment Institution.

Table V. Number of an annual specimens.

\begin{tabular}{|r|r|}
\hline Year & $\begin{array}{r}\text { Number of } \\
\text { specimens }\end{array}$ \\
\hline 1982 & 118,002 \\
\hline 1983 & 164,317 \\
\hline 1984 & 185,636 \\
\hline 1985 & 212,986 \\
\hline 1986 & 272,483 \\
\hline Total & 953,424 \\
\hline
\end{tabular}

Table VI. Number of an annual specimens and fracture ratio of joint.

\begin{tabular}{|c|c|r|l|}
\hline Year & $\begin{array}{c}\text { Number of } \\
\text { specimens }\end{array}$ & $\begin{array}{c}\text { Number of } \\
\text { fractured } \\
\text { joints } \\
(\mathrm{B})\end{array}$ & $\begin{array}{l}\text { Fracture } \\
\text { ratio of } \\
\text { joint } \\
(\mathrm{B}) /(\mathrm{A}) \%\end{array}$ \\
\hline 1982 & 118,002 & 377 & 0.32 \\
\hline 1983 & 164,317 & 806 & 0.49 \\
\hline 1984 & 185,636 & 938 & 0.51 \\
\hline 1985 & 212,986 & 1,047 & 0.49 \\
\hline 1986 & 272,483 & 1,383 & 0.51 \\
\hline Total & 953,424 & 4,551 & 0.48 (Ave.) \\
\hline
\end{tabular}

は神戸市附近の試験機関で, 神戸市内で建設される建物 の試験片が多数依頼されていると言われる機関であるが, 継手破断比率は $0.43 \%$ と Table VIの平均值とほほ同程度 の值であり，他の地域と比べて特に継手破断比率が大き い傾向は見られない。このことは, 兵庫県南部地震から 得られた継手破断のデータは全国の平均值的な実状を示 している考えてもさほど大きな䛊差を含んでいないこと を示していると思われる。

\section{$5 \cdot 2$ 継手破断強度の検討用データ}

本データの中で, 継手破断強度の分布性状を検討する のに用いたデータは, Table VIに示した継手破断したデ 一タの内, SD35, D22 D29 の 3220 本のデータ（以下， このデータを全国データという）である。そ理由は兵 庫県南部地震での兵庫データと比較する意味で, 鉄筋種 
Table VII. Number of specimens and fracture ratio of joint in each diameter of reinforcement.

\begin{tabular}{|l|r|r|r|r|r|r|}
\hline $\begin{array}{l}\text { Classification } \\
\text { of } \\
\text { reinforcement }\end{array}$ & \multicolumn{2}{|c|}{ SD30 } & \multicolumn{2}{|c|}{ SD35 } & \multicolumn{2}{c|}{ Total } \\
$\begin{array}{l}\text { Diameter of } \\
\text { reinforcement }\end{array}$ & $\begin{array}{r}\text { Number of } \\
\text { specimens }\end{array}$ & $\begin{array}{r}\text { Number of } \\
\text { fractured } \\
\text { joints }\end{array}$ & $\begin{array}{r}\text { Nu mber of } \\
\text { specimens }\end{array}$ & $\begin{array}{c}\text { Number of } \\
\text { fractured } \\
\text { joints }\end{array}$ & $\begin{array}{r}\text { Nu mber of } \\
\text { specimens }\end{array}$ & $\begin{array}{r}\text { Number of } \\
\text { joints }\end{array}$ \\
\hline D16 & 4,121 & 16 & 616 & 5 & 4,737 & 21 \\
\hline D19 & 53,793 & 74 & 72,118 & 101 & 125,911 & 175 \\
\hline D22 & 99,666 & 218 & 203,076 & 564 & 302,742 & 782 \\
\hline D25 & 90,382 & 385 & 322,150 & 2,077 & 412,532 & 2,462 \\
\hline D29 & 17,859 & 122 & 64,483 & 579 & 82,342 & 701 \\
\hline D32 & 12,502 & 211 & 12,658 & 199 & 25,160 & 410 \\
\hline Total & 278,323 & 1,026 & 675,101 & 3,525 & 953,424 & 4,551 \\
\hline $\begin{array}{l}\text { Average raito } \\
\text { of fractured } \\
\text { joint (\%) }\end{array}$ & & 0.37 & & 0.52 & & 0.48 \\
\hline
\end{tabular}

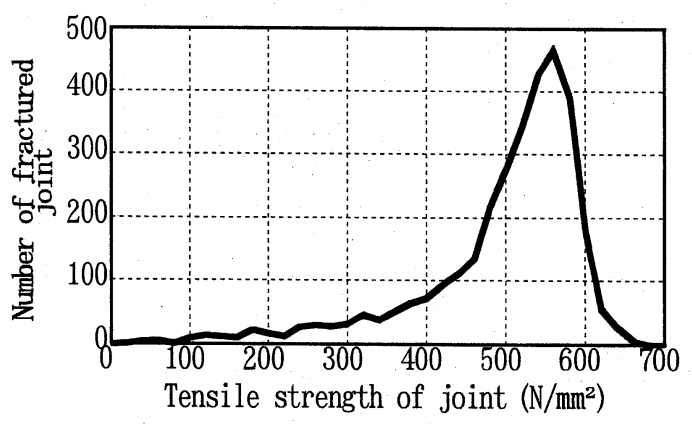

Fig. 7. Distribution of tensile strength of Fractured joints on National data.

Table VIII. Comparison between Hyogo data and National data.

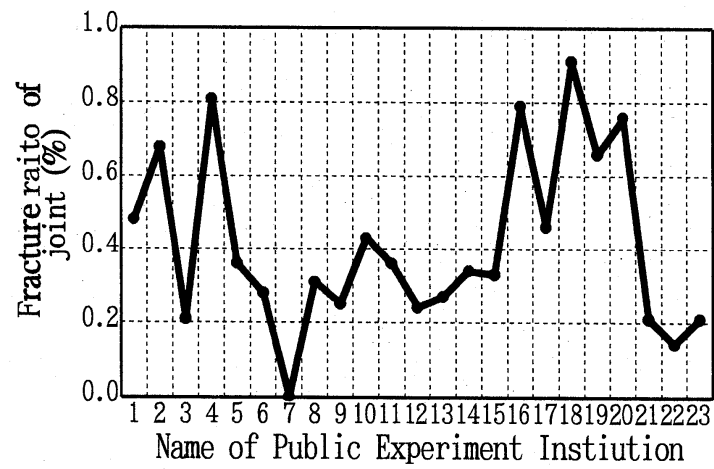

\begin{tabular}{|c|c|c|r|r|r|}
\hline $\begin{array}{c}\text { Classification } \\
\text { of } \\
\text { data }\end{array}$ & $\begin{array}{c}\text { Classification } \\
\text { of } \\
\text { reinforcement }\end{array}$ & $\begin{array}{c}\text { Diameter } \\
\text { of }\end{array}$ & $\begin{array}{c}\text { Number } \\
\text { of } \\
\text { specimens } \\
\text { (A) }\end{array}$ & $\begin{array}{c}\text { Number } \\
\text { of } \\
\text { fractured } \\
\text { joints (B) }\end{array}$ & $\begin{array}{c}\text { Fracture } \\
\text { ratio of } \\
\text { joint } \\
(B) /(A) \%\end{array}$ \\
\hline Hyogo data & SD35 & D22 2 D29 & 180 & 32 & 17.78 \\
\hline National data & SD35 & D22 2 D29 & 589,709 & 3,220 & 0.55 \\
\hline
\end{tabular}

Table IX. Minimum, maxmum, average and standard deviation of Hyogo data and National data.

\begin{tabular}{|c|c|c|c|c|c|}
\hline \multirow{3}{*}{$\begin{array}{c}\text { Classification } \\
\text { of } \\
\text { data }\end{array}$} & \multirow{3}{*}{$\begin{array}{l}\text { Number of } \\
\text { fractured } \\
\text { joints }\end{array}$} & \multicolumn{4}{|c|}{ Tensile strength } \\
\hline & & Minimu & Maximum & Averag & tandard \\
\hline & & $\left(\mathrm{N} / \mathrm{mm}^{2}\right)$ & $\left(\mathrm{N} / \mathrm{mm}^{2}\right)$ & $\left(\mathrm{N} / \mathrm{mm}^{2}\right)$ & $\begin{array}{l}\text { deviation } \\
\left(\mathrm{N} / \mathrm{mm}^{2}\right)\end{array}$ \\
\hline Hyogo data & 32 & 240 & 564 & 490 & 75 \\
\hline National data & 3220 & 38 & 661 & 495 & 101 \\
\hline
\end{tabular}

別 (SD35)，鉄筋径 (D22〜D29) を同一範囲にしたため である.

Fig. 7 に全国データの破断強度分布をダイアグラムで 示した. Fig. 4 の兵庫県南部地震の兵庫データの分布と よく近似している.

\section{6 ガス圧接継手の継手強度の再評価}

\section{$6 \cdot 1$ 兵庫データと全国データの比較}

兵庫データと全国データは近似した性状を示している が，ここでは両データを比較してみる。比較した両デー タの詳細を Table 䜣に示した. Table VIIIの兵庫データで 試験片数が 180 本となっているのは，鉄筋径を比較検討 のため D22 〜 D29 の範囲にそろえたので Table IVの 182 本から D19の 2 本を除いたためである. Table XXに両デ 一タの継手強度の最小值, 最大值, 平均値拝よび標準偏 差を示した。両データの各值は近似していることが認め られる。

Fig. 8 は兵庫データ (32 本) と全国データ (3220 本) を基準として継手破断比率の度数をダイアグラムで示し たものである。両者の分布形状はよく近似していること が分かる. Fig. 9 は兵庫データと全国データの累積破断 比率を比較したものであるが，両者の值はよく近似して いる.

Fig. 8, Fig. 9 から分かるように兵庫データと全国デー 夕の両者は比較的よく類似した性状を示していることが 分かる。このことは，ガス圧接継手の継手破断強度を再

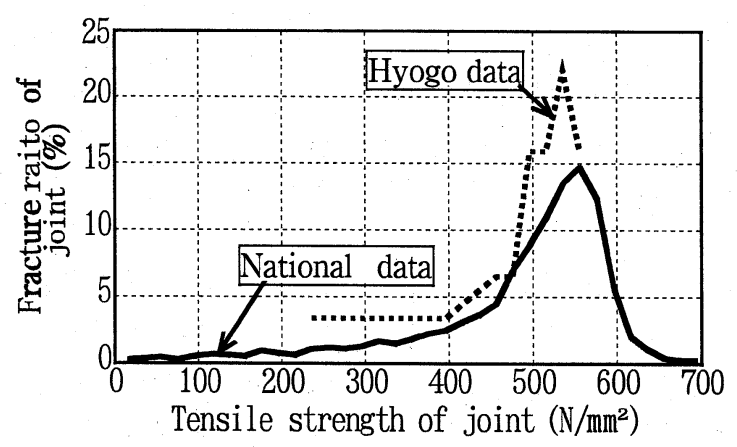

Fig. 8. Camparison of fracture ratio between Hyogo data and National data.

National data.

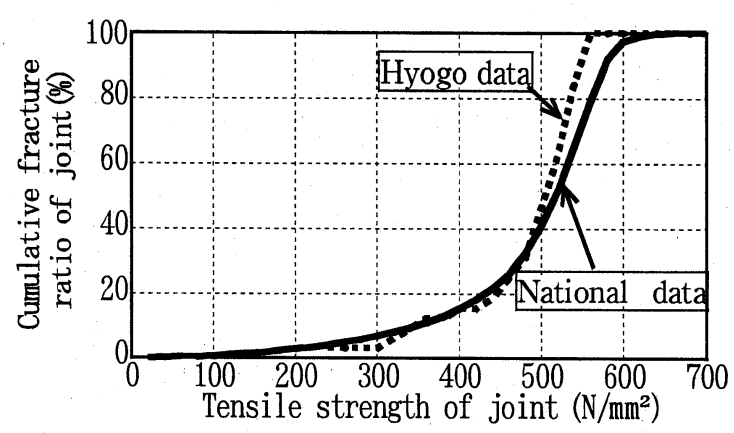

Fig. 9. Cumulative fracture ratio of joint between Hyogo data and National data. 
Table $X$. Fracture ratio of joint under $\sigma_{y}$ and $1.35 \sigma_{y}$ in Hyogo data and National data.

\begin{tabular}{|r|r|r|}
\hline \multirow{2}{*}{$\begin{array}{c}\text { Tensile } \\
\text { strength }\end{array}$} & \multicolumn{2}{|c|}{ Fracture ratio of joint (\%) } \\
\cline { 2 - 3 } & Hyogo data & National data \\
\hline$\sigma \mathrm{y} /$ & $\mathbf{9 . 4}$ & $\mathbf{9 . 1}$ \\
\hline $1.35 \sigma \mathrm{y} / \prime$ & $\mathbf{2 1 . 9}$ & $\mathbf{2 3 . 9}$ \\
\hline
\end{tabular}

評価する場合，兵庫データだけでなく全国データも十分 利用できることを示唆している。

\section{$6 \cdot 2$ 継手強度の再評価}

ここでは兵庫データおよび全国データをもとにガス圧 接継手の継手強度の再評価の 1 例を示す. 継手強度を評 価する方法として各種考えられるが，ここでは継手破断 した継手の中で特定応力以下で継手破断が発生する比率 (以下，継手破断発生比率）を用いて評価する手法を示 す. 特定応力としては, 部材の破壞性状として曲げ破壊 とせん断破壊の 2 種を想定し，それぞれの終局時の材端 での主筋に生じると考えられる最大応力度を $\sigma_{y}$ (JIS の 規格降伏点 $\left.345 \mathrm{~N} / \mathrm{mm}^{2}\right)$ と $1.35 \sigma_{y}$ と仮定する. $1.35 \sigma_{y}$ は 機械的継手指針の性能値にあわせたものである，兵庫デ 一タと全国データに扔ける $\sigma_{y}$ と $1.35 \sigma_{y}$ での継手破断発生 比率は Table Xのようになる. 両者の継手破断発生比率 は非常によく近似している. 即ち, 調查方法が全く異な る兵庫データと全国データがよく近似した值を示すとい うことは，既存コンクリート䒺建築物で使用されている ガス圧接継手の継手強度と継手破断比率の関係は Table Xの継手破断発生比率を考慮して再評価する必要がある ことを意味している。，従来のガス圧接継手の継手強度は 母材とほぼ同等と評価されてきたわけであるから, Table Xでの継手破断発生比率はいずれもゼロとして評価され てきたことになる. Table Xは明らかに従来の評価が危 険側の評価であることを示している.

\section{7 ま と め}

ガス圧接継手の継手強度は従来ほぼ母材と同等である と評価されていたが, 兵庫県南部地震ではコンクリート 系建築物で使用されていたガス圧接継手に多くの継手破 断の被害が発生した。 そこで, 被災後解体された建物 8 棟から 365 本の試験片を採取し引張試験調查を行った結 果，その継手破断比率は平均で $12.6 \%$ と相当に大きな值 を示した。

このように大きな継手破断比率を示す継手の継手強度 を従来と同様に評価するのは困難であり, 新たに継手破 断強度の分布について論ずる必要があると考え，本報で は既存コンクリート系建築物で使用されているガス圧接
継手に限定して，元れらガス圧接継手の継手破断強度の 再評価について検討した結果, 次のことが認められた。

(1) 外観調查の結果, 調査建物 60 棟の内, 外観から ガス圧接継手が確認できた建物は 22 棟あった。矢の 22 棟中継手破断が 7 棟で見られ, 継手破断が見られた建物 の比率がかなり高い.

外観から確認されたガス圧接継手のみについて単純に ガス圧接継手の継手破断比率を求めてみると, $31 / 279=$ $11.1 \%$ となる。

(2) 被害建物 8 棟から 356 本の試験片を採取し引張 試験を行った結果，建物別の継手破断比率は $0 \sim 27.3 \%$ の広範囲に分布し，継手破断比率は各建物によって異な るが, 全平均は $12.6 \%$ であった。

ガス圧接継手の継手強度に関する従来の評価は, 母材 とほぼ同等であるとして扱われてきたが, 継手破断比率 の平均値が $12.6 \%$ であることから考えると, 既存建築物 で使用されているガス圧接継手の継手強度に関しては従 来の評価をそのまま適用できない，即ち，既存コンクリ 一ト系建築物で使用されているガス圧接継手の継手強度 については再評価が必要であることが認められた。

（3）兵庫データおよび全国データを用いて継手破断し た継手の中で $\sigma_{\mathrm{y}}$ 拉よび $1.35 \sigma_{\mathrm{y}}$ 以下で継手破断が発生す る継手破断発生比率を示し, ガス圧接継手の継手強度の 再評価の 1 例を示した。

本調査を行うに当たり関係各位の御協力を賜りました。 心より御礼申し上げます。特に，(㑣新井組の中沢明夫氏， 秦 邦晃氏，神戸市役所の赤松恵一朗氏，小池敬二氏， 山本隆史氏, 神戸市議会議員の平野章三氏には各調査に 当たり大変御世話になり感謝いたします。 また, 大阪大 学工学部建築学科鈴木計夫教授 (現在 福井工業大学教 授），大野義照教授には調査データの提供などを頂きまし た。紙面を借り，厚く御礼申し上げます。

\section{参 考 文 献}

1) 田中礼治, 大劳賀義喜, 日本建築学会構造系論文報告集, №. 393, p.46 (1988).

$2 ）$ 日本建築学会, “1987 年宮城県沖地震災害調査報告” (1980).

3 ） 日本建築学会, “1994 年北海道東方沖地震災害調查報告 1994 年三陸はるか沖地震災害調查報告”（1996）。

4) 熊谷元行, 小澤昌広, 田中礼治, 1997 年度日本建築学会 大会学術講演梗概集, p.471 (1997).

5) 田中礼治, 熊谷元行, 小澤昌広, 1997 年度日本建築学会 大会学術講演梗概集, p.473 (1997). 